Research article

\title{
STATISTICAL EVALUATION OF THE LARVICIDAL EFFECT OF DIFLUBENZURON ON CULEX PIPIENS LARVAL STAGES
}

\author{
DJORDJEVIĆ Milutin ${ }^{1 *}$, MIRILOVIĆ Milorad ${ }^{2}$, STAJKOVIĆ Novica ${ }^{3}$ JANKOVIĆ \\ Ljiljana ${ }^{1}$, PEŠIĆ Branislav ${ }^{4}$, BOKONJIĆ Dubravko ${ }^{3}$, DJURIĆ Spomenka ${ }^{2}$
}

\footnotetext{
${ }^{1}$ Department of Zoohygiene, Faculty of Veterinary Medicine University of Belgrade, Belgrade, Serbia; ${ }^{2}$ Department of Economic and Statistics, Faculty of Veterinary Medicine University of Belgrade, Belgrade, Serbia; ${ }^{3}$ Military Medical Academy, Belgrade, Serbia; ${ }^{4}$ Institute for Biocides and Medical Ecology, Belgrade, Serbia
}

(Received 14 October; Accepted 27 November 2015)

Diflubezuron is increasingly used in areas where mosquito larvae developed resistance to other insecticides. In our community diflubenzuron is not used to control mosquito larvae. Two formulations of 1\% diflubenzuron (on corn-cob EF-1, and zeolite EF-2) were tested on Culex pipiens L (larvae) on one canal in the Belgrade suburb area. The effect was followed for seven weeks after application of the formulations. Formulation EF1 achieved a reduction in mosquito $\mathrm{L}_{1} \mathrm{~L}_{2}$ larvae between $23.9 \%$ and $89.4 \%$. The change was statistically significant the $21^{\text {st }}$ and $28^{\text {th }}$ day $(p<0.001), 35^{\text {th }}$ and $42^{\text {nd }}$ day $(\mathrm{p}<0.01)$ and $49^{\text {th }}$ day $(\mathrm{p}<0.05)$. The maximal reduction obtained by formulation EF2 was $69.1 \%$. The accomplished reduction was significant on the $28^{\text {th }}$ and $42^{\text {nd }}$ day $(\mathrm{p}<0.001), 35^{\text {th }}$ day $(\mathrm{p}<0.01)$ and $21^{\text {st }}(\mathrm{p}<0.05)$. Both formulations have maintained a good residual effect on the lower developmental larval stages. Maximum reduction achieved by EF1 on $\mathrm{L}_{3} \mathrm{~L}_{4}$ larvae was $97.4 \%$. Reduction of larvae was high between the $7^{\text {th }}$ and $42^{\text {nd }}$ day $(66.4-97 \%)$. Statistically significant values were recorded on the $21^{\text {st }}, 28^{\text {th }}$ and $35^{\text {th }}$ day. Formulation EF2 achieved a reduction of $99.5 \%$. A statistically significant reduction in the value of mosquito larvae was obtained on the $14^{\text {th }}, 21^{\text {st }}, 28^{\text {th }}$, $35^{\text {th }}$ and $42^{\text {nd }}$ day.

Between the two used formulations there was no significant difference in the number reduction of lower larval stages, but for the higher larval stages EF1 proved to be more efficient.

Key words: diflubenzuron, formulation, cob, zeolite, larvae, mosquito, Culex pipiens L.

\section{INTRODUCTION}

Mosquitoes are vital insect species regardless of changing environmental and climatic factors, host species and habitat status. Although part of their life cycle is related to the aquatic environment, mosquitoes are biological vectors of numerous known and still

*Corresponding author: e-mail: milutin@vet.bg.ac.rs 
undiscovered infectious agents [1-5]. The most successful form of protection from the transmission of agents are lack of contact with mosquitoes and reduction of their numbers [6,7]. This is not easy when one takes into consideration their diversity, breeding potential, size and mobility. Reduction of the number of mosquitoes can be achieved through changes of conditions for their maintenance on the site, use of protective clothing, nets, and repellents [8,9]. During the suppression of mosquito larvae with larvicides of chemical and microbial origin, as well as growth regulators, resistance can develop. Resistance can be accelerated due to an unplanned and uncontrolled use of these substances. Even before the appearance of organic insecticides, resistance to inorganic insecticides was registered in 12 species of arthropods [10]. In 1946 resistance was detected in two species of insects, in 1980 in 150 species, and in 1990 resistance was detected in 198 species. According to the World Health Organization (1992) resistance was disclosed in 56 species of mosquitoes of the genus Anopheles, 19 species of mosquitoes of the genus Aedes and 20 mosquito species of the genus Culex. Resistance was detected in larvae and adult individuals [11]. By 2008 resistance was detected in 553 arthropod species, of which 202 species are of public health importance [12].

The Belgrade environment offers conditions for the development and survival of a number of mosquito species among which a few are primary vectors of malaria, dirofilaria and some arboviral infections [13-16]. In the Belgrade district the presence of potential malaria carriers Anopheles mosquitoes has been previously described [15]. On Belgrade city territory in year 2012 in Culex pipiens mosquitoes the presence of West Nile virus was recorded [17]. In the earlier period adult mosquito forms were controlled with malathione based compositions, permethrine, lambdacihalotrine and deltamethrine [18]. The long term use of organophosphate larvicides in the Belgrade area, as well as lack of information pertaining the resistance to larvicides, and their removal from the list of allowed biocides had influenced the need to study the effects of alternative substances for the control and elimination of mosquito larvae [19-21]. In the recent years there is an increased interest in studies on the larvicidal effects of diflubenzuron based formulations. These formulations are recommended by the World Health Organization [7,22] and the European Commission for Biocides.

In this paper we have studied the larvicidal effects of $1 \%$ diflubenzuron applied on two different carriers in a granular formulation with a granule diameter of 0.7 and $2.0 \mathrm{~mm}$. The aim of our trial was to study the efficacy of the tested formulations on different mosquito larval stages in order to assess their potential application in mosquito control programs in the Belgrade area.

\section{MATERIAL AND METHODS}

Two granulated 1,0\% diflubenzuron 1-(4-chlorophenyl)-3-(2,6-difluorobenzoyl)-urea formulations ( $96 \%$ a.i. Radon China Product Chemestry) were tested on Culex pipiens L. mosquito larvae in a dose of $100 \mathrm{~g}$ a.i. per hectare of treated water surface. In the 
experimental formulation 1 (EF 1) the difluobenzene was corncob in the form of $0.7 \mathrm{~mm}$ granules. The carrier used in experimental formulation 2 (EF 2) was zeolite in the form of $2 \mathrm{~mm}$ granules. The percentage share of diflubenzuron in the formulations was determined by gas chromatography and for both formulations measured $1.0 \%$.

The trial was carried out in the Belgrade area on a hydromelioration channel on the Danube left bankshore ( $44^{\circ} 53$ '29.7 “N $20^{\circ} 27^{\prime \prime}$ “20, 61” S; altitude 70m, Borca canal). The channel was $820 \mathrm{~m}$ long, $2.5 \mathrm{~m}$ wide and $0.4-0.6 \mathrm{~m}$ deep. The water was slow-moving and rich in organic waste material. For the here presented study three $100 \mathrm{~m}$ sections of the channel were selected with a $100 \mathrm{~m}$ buffer zone between each of the sections. The first $100 \mathrm{~m}$ section, with an area of $250 \mathrm{~m}^{2}$, was taken as the control. Between the control area and the area treated with EF1 $\left(250 \mathrm{~m}^{2}\right)$ there was an untreated buffer zone whose area was $250 \mathrm{~m}^{2}$, also. Concurrently, between the EF1 treated zone and the EF2 treated zone there was an untreated $250 \mathrm{~m}^{2}$ zone. The areas treated with formulations EF1 and EF2 were subjected to $250 \mathrm{~g}$ preparation based on $1 \%$ difluobenzuron $(2.5 \mathrm{~g}$ a.i. diflubenzuron per $250 \mathrm{~m}^{2}$ water surface). Prior to treatment (August 2012) 8 water samples from every previously mentioned section were taken at $10 \mathrm{~m}$ intervals. Each sample volume was $250 \mathrm{ml}$ in order to assess the number of larvae, their stage of development and the species of larvae present. Mosquito species were determined on the basis of morphological characteristics of the developmental stages of larvae according to the identification key described by Utrio [23]. Water temperature was measured using a Trotec ${ }^{\circledR}$ BT-20 thermometer and air temperature by Kestrel $4000^{\circledR}$ weather station during the treatment and at each control.

Before the treatment water samples were taken in order to monitor the following parameters: biological oxygen demand $\left(\mathrm{BOD}_{5}\right)$ - method with ion selective electrodes using a portable oximeter DO6 + - EUTECH and cooling thermostat with ET 618-4; chemical oxygen demand (COD) - Dihromat/ $\mathrm{H}_{2} \mathrm{SO}_{4}$ method, total nitrogen - persulphate digestion method, free ammonia - salicylate method, nitrates - method with chromotropic acid, sulfates - method with barium sulphate turbidity, phosphates - a method with ammonium molybdate and water hardness- method using a photometer with metalphtalein Multidirect LOVIBOND and Thermoreactors RD 125 - LOVIBOND;

turbidity was determined by using the formazin standard Fotometar checkdirect turbidity - LOVIBOND, $\mathrm{pH}$ value was determined using a $\mathrm{pH}$ meter - EUTECH; dissolved oxygen was measured using a portable oxymeter DO6 + - EUTECH.

The experiment started on the $10^{\text {th }}$ August 2012 with the application of EF 1 and EF 2 on both waterbanks along the observed water sections in a width of $50 \mathrm{~cm}$. Both experimental surfaces were treated with $250 \mathrm{~g} 1.0 \%$ diflubenzuron. Testing the 
efficiency of the above formulations on mosquito larvae was performed at: $24 \mathrm{~h}, 48 \mathrm{~h}$, 72h, 7, 14, 21, 28, 35, 42 and 49 days from treatment. Throughout the experiment eight water samples were taken at each location with a dipper in a volume of $250 \mathrm{ml}$ per sample. The larvae were counted and grouped according to different stages of development.

Estimation of the efficiency of the described diflubenzuron formulations was done according to the developmental stage of the larvae, earlier $\mathrm{L}_{1}$ and $\mathrm{L}_{2}$ stages were observed separately from the late $\mathrm{L}_{3} \mathrm{~L}_{4}$ stages, according to the formula:

$$
E=100-\frac{C 1}{T 1} \cdot \frac{T 2}{C 2} \cdot 100
$$

$\mathrm{E}=$ reduction effect, expressed in percent

$\mathrm{C}_{1}=$ number of larvae in the control channel before treatment

$\mathrm{T}_{1}^{1}=$ number of larvae in the control channel after treatment

$\mathrm{T}_{2}=$ the number of larvae in the treated channel before treatment

$\mathrm{C}_{2}^{2}=$ number of larvae on the control channel after treatment

Statistical analysis of the obtained results included descriptive statistical parameters. These parameters enabled us to describe and interpret the obtained experimental results. In the process of testing and describing the statistically significant differences analysis of variance was applied. Kolmogorov-Smirnov Test for normality was used to determine whether sample data were normally distributed. As the obtained data was not normally distributed and the data depth series was small Kruskall-Wallis non parametric variance analysis was performed. Individual comparisons were performed with the Mann-Whitney U test and Dunn's multiple comparisons test. Level of significance was set at 5,1, and $0.1 \%$. Correlation analysis defined the strength of the dependence of the analyzed parameters expressed as Pierson's coefficient of linear correlation $\left(\mathrm{r}_{\mathrm{xy}}\right)$. Statistical analysis of the obtained results was carried out with the aid of the statistical package PASW Statistics 18 and MS Excel.

\section{RESULTS}

Evaluation of the efficacy of two formulations based on $1.0 \%$ diflubenzuron on corncob and zeolite was carried in the Belgrade suburb district on a channel infested with $C x$. pipiens L. mosquito larvae (Picture 1). The presence of overflowing septic tanks into the canal where the experiment was organized influenced the change of water quality and the increased presence of organic and inorganic substances that contributed to the development of $C x$. pipiens $L$. mosquito larvae. The tested water samples measured increased concentration values of ammonia, total nitrogen, organic phosphorus and hardness compared to the average values measured for ammonia, total nitrogen and organic phosphates concentrations, as well as water hardness (Table $1)$. 


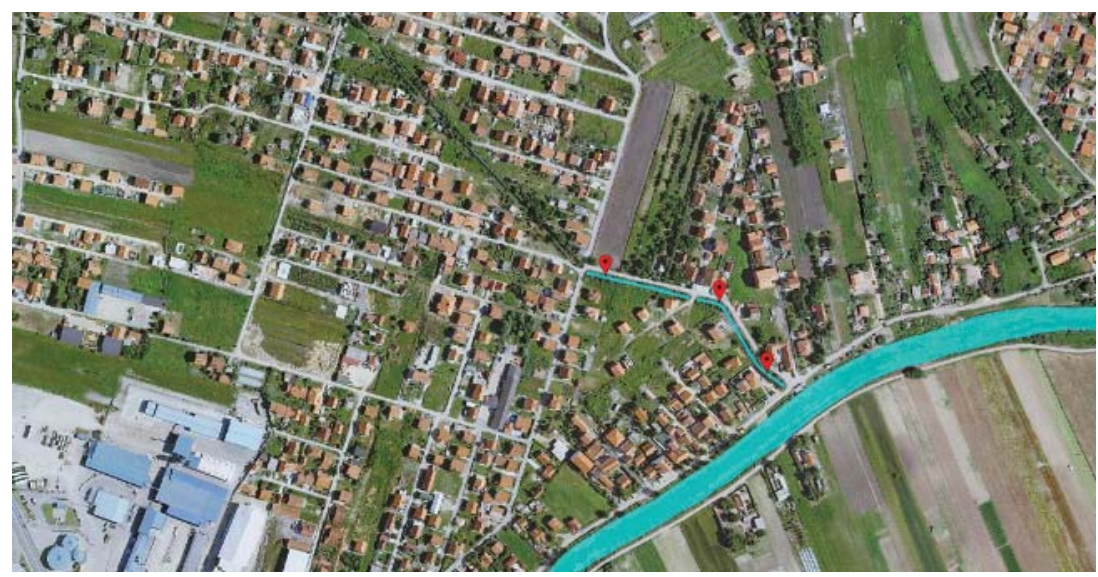

Picture 1. Geographical coordinates of the location on which the study was carried out

Table 1. Some indicators of water quality in the Belgrade suburb distrit (Borča water canal)

\begin{tabular}{lcc}
\hline Type of analysis & Values obtained & $\begin{array}{c}\text { Marginal velues of } \\
\text { pollutants }\end{array}$ \\
\hline Nitrates & $0 \mathrm{mg} / \mathrm{l}$ & $3 \mathrm{mg} / 1$ \\
\hline Ammonia & $12.4 \mathrm{mg} / 1$ & $0,3 \mathrm{mg} / 1$ \\
\hline Total nitrogen & $60 \mathrm{mg} / 1$ & $3 \mathrm{mg} / 1$ \\
\hline Sulfates & $99.7 \mathrm{mg} / 1 \mathrm{SO}_{4}$ & $100 \mathrm{mg} / 1$ \\
\hline Phosphates & $10.1 \mathrm{mg} / 1$ & $0,1 \mathrm{mg} / 1$ \\
\hline Chemical $\mathrm{O}_{2}$ consumption & $71 \mathrm{mg} / 1 \mathrm{O}_{2}$ & $15 \mathrm{mg} / 1 \mathrm{O}_{2}$ \\
\hline Biological $\mathrm{O}_{2}$ consumption & $4.38 \mathrm{mg} / 1 \mathrm{O}_{2}$ & $\mathrm{do} 5 \mathrm{mg} / 1 \mathrm{O}_{2}$ \\
\hline Dissolved oxygen & $1.2 \mathrm{mg} / 1$ & $7 \mathrm{mg} / 1$ \\
\hline pH & 7.2 & $6,5-8,5$ \\
\hline Water temperature & $22.8^{\circ} \mathrm{C}$ & $15-30^{\circ} \mathrm{C} *$ \\
\hline
\end{tabular}

* optimal temperature for development of larvae

Throughout the experiment regular measurements of water and air temperature were taken. During the trial there was no statistical difference $(\mathrm{p}>0.05)$ in water temperature between the diflubenzuron treated (EF1 and EF2) sections and the control. Water temperature in the canal was in the range between 15.1 and $24.6{ }^{\circ} \mathrm{C}$ (Figure 2). Air temperature varied between $8.5^{\circ} \mathrm{C}$ in the morning hours and maximal $39.5^{\circ} \mathrm{C}$ in the daytime (Figure 1). No statistically significant differences $(\mathrm{p}>0.05)$ were recorded between the treated areas (EF 1 and EF 2) and the control section of the canal. 


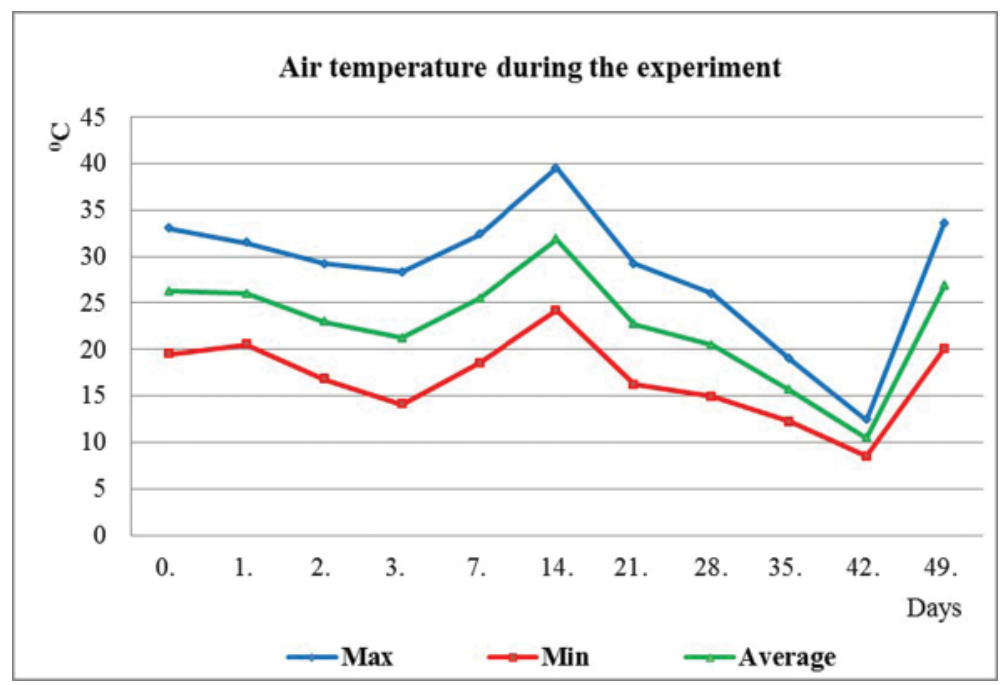

Figure 1. Air temperature during the experiment

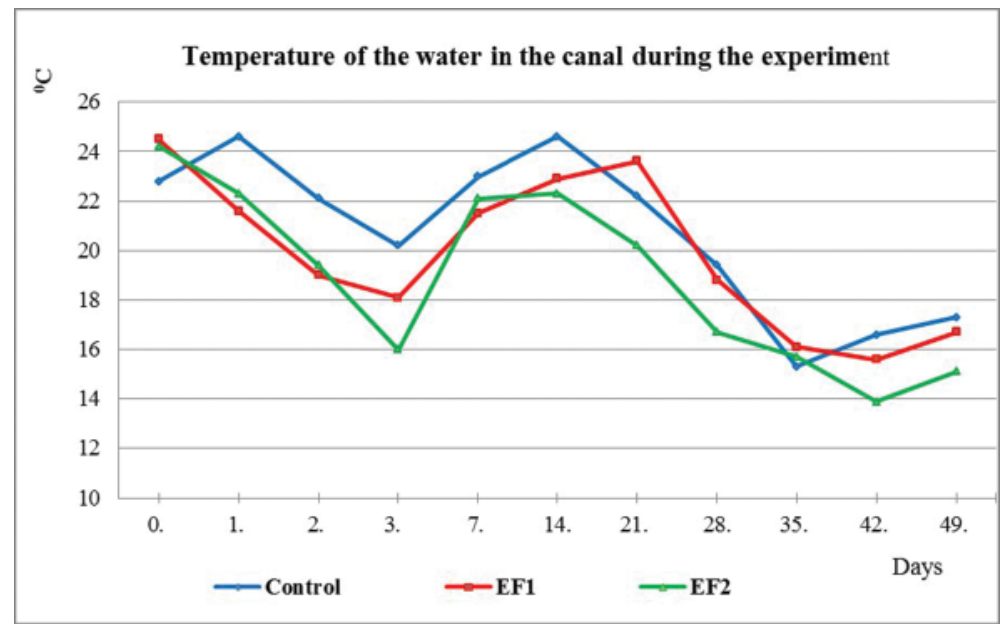

Figure 2. Temperature of the water in the canal during the experiment

The degree of correlation between the presence of mosquito larval stages and water temperature was established according to Pierson-s coefficient of linear correlation. A significant correlation was described between larval stages $\mathrm{L}_{3} \mathrm{~L}_{4}$ in the control section $(\mathrm{p}<0.05)$ and $\mathrm{L}_{1} \mathrm{~L}_{2}$ in the EF1 and EF2 sections $(\mathrm{p}<0.05)$. (Table 2.).

A reduction on the number of lower developmental $C x$. pipiens larval stages $\left(\mathrm{L}_{1}\right.$ and $\left.\mathrm{L}_{2}\right)$ in the treated water sections (EF1 and EF2) was registered the first day after treatment. Formulation EF1 induced a reduction of $48.7 \%$ and formulation EF2 induced a decrease by $47.7 \%$. 
Table 2. Correlations between developmental stages of $C x$. pipiens mosquitoes and water temperature

\begin{tabular}{lllll}
\hline CANAL & $\mathbf{L}_{1} \mathbf{L}_{2}$ & & $\mathbf{L}_{\mathbf{3}} \mathbf{L}_{4}$ & \\
\hline \multirow{2}{*}{ CONTROL } & $\mathrm{r}=0.4540$ & & $\mathrm{r}=0.6689$ & \\
& $\mathrm{p}=0.161$ & & $\mathrm{p}=0.024$ & $\mathrm{p}<0,05$ \\
EF1 & $\mathrm{r}=0.6621$ & & $\mathrm{r}=0.4320$ & \\
& $\mathrm{p}=0.026$ & $\mathrm{p}<0,05$ & $\mathrm{p}=0.185$ & \\
EF2 & $\mathrm{r}=0.702$ & & $\mathrm{r}=0.4752$ & \\
& $\mathrm{p}=0.016$ & $\mathrm{p}<0,05$ & $\mathrm{p}=0.140$ & \\
\hline
\end{tabular}

The correlations are significant at $\mathrm{p}<0.05$ L- larvae

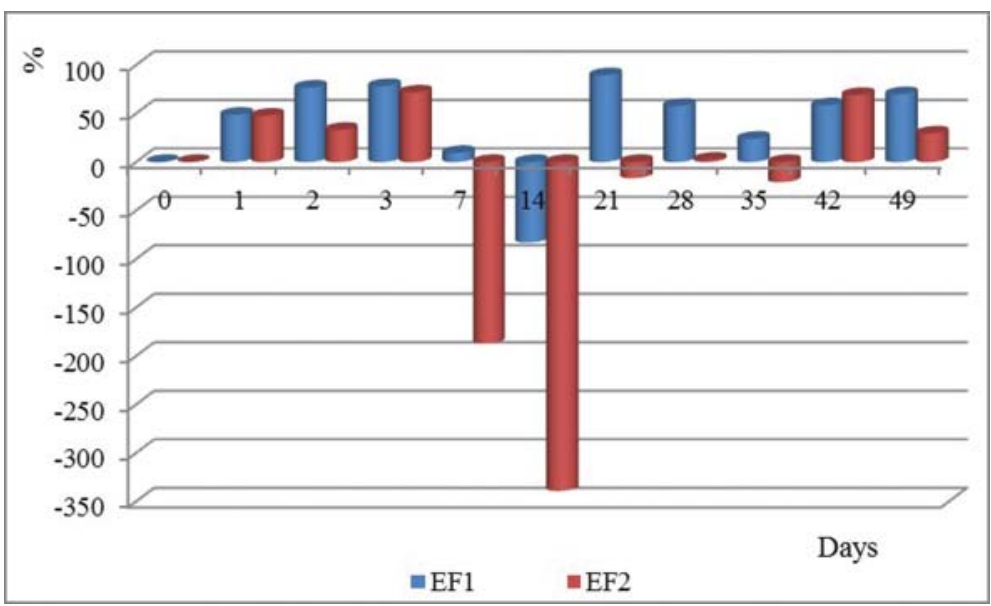

Figure 3. Reduction of the number of L1, L2 larvae due to EF1 and EF2 treatment, expressed as percents

The reduction in the number of larvae in the EF1 treated section increased between the first and third day from $48.7 \%$ to $78.2 \%$. In the same three-day period EF2 treatment resulted in a decrease in reduction on the second day. During the first three days the reduction rate was $47.7 \%$ the first day, $33.2 \%$ the second day, and $71.6 \%$ the third day after EF2 treatment. Formulation EF1induced a reduction in the number of larvae on the $7^{\text {th }}$ and $14^{\text {th }}$ day after treatment, thereon it increased to a maximum on the $21^{\text {st }}$ day when it measured 89.4\%. (Figure 3.)

Formulation EF2 resulted in a negative reduction in the number of larvae on days $7,14,21$, and 35 . On days 28, 42, and 49 the same formulation resulted in a positive reduction which ranged between $2.36 \%$ and $69.01 \%$.

EF1 formulation showed better results during the experimental 7 weeks in the number reduction of $C x$. pipiens $L$. lower larval stages compared to EF2. Both formulations showed a residual activity on $\mathrm{L}_{1}, \mathrm{~L}_{2}$ mosquito larvae during the trial period.

Analysis of the significance relative to day zero in the water treated with formulation EF1 measured significant values on day 3 ( $p<0.05), 21,28,35,42$ and $49(\mathrm{p}<0.01)$. 
Statistical analysis of the larvicidal effect of formulation EF2 relative to day zero was significant $(\mathrm{p}<0.05)$ on day 21 , and $(\mathrm{p}<0.01)$ on days 21,35 , and 42 .

Analysis of the statistical significance in $\mathrm{L}_{1}, \mathrm{~L}_{2}$ larvae number reduction for both formulations, showed that formulation EF1 significantly $(p<0.01)$ reduced the number of larvae on the first day when compared to the control untreated section. Comparisons of the reduction numbers throughout the trial period showed no statistical significance $(\mathrm{p}>0.05)$. (Figure 4.).

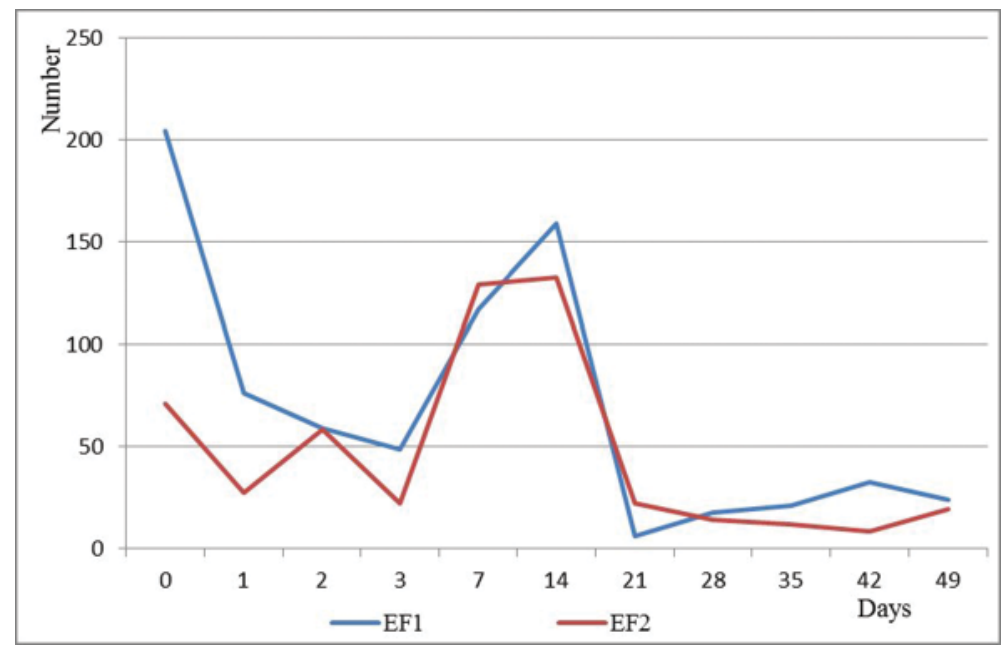

Figure 4. Comparison of the effects of EF1 and EF2 formulations on the reduction of the number of L1, L2 larvae

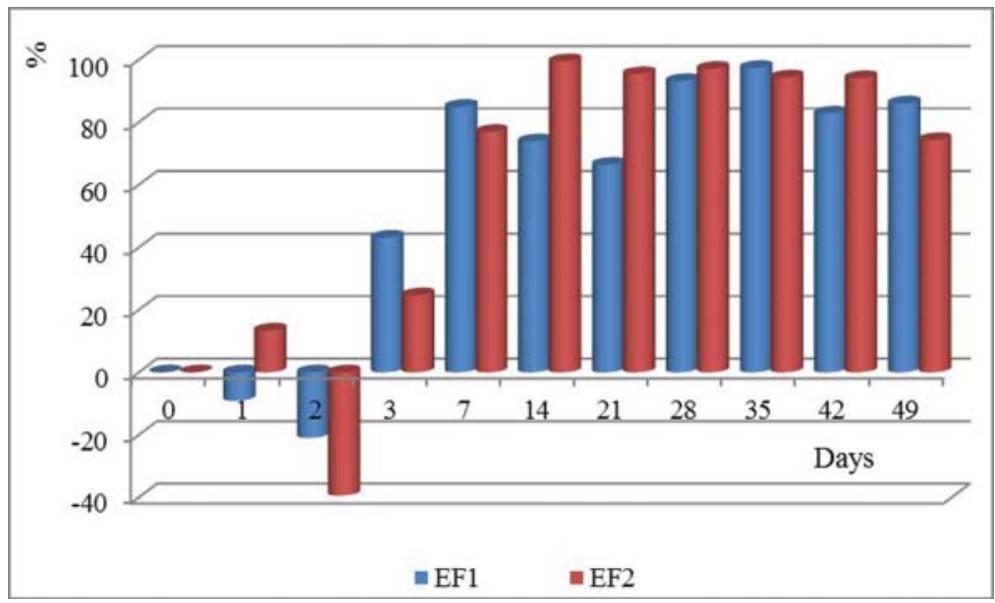

Figure 5. Reduction of the number of L3, L4 larvae due to EF1 and EF2 treatment, expressed as percents

Higher developmental stages of $C x$. pipiens larvae $\left(\mathrm{L}_{3}, \mathrm{~L}_{4}\right)$ treated with EF1 and EF2 the first and second day after treatment did not show a positive reduction in the number of larvae. Such reduction was recorded on the third day after treatment of the 
EF1 treated canal sector, when it reached $43.1 \%$ compared to day zero. In the canal sector treated with EF2 the reduction in the number of larvae on the first day after treatment was $13.4 \%$. In the following days the EF1 treated mosquito larvae showed a reduction in their number which ranged from $66.6 \%$ to $97.4 \%$. In the same period the EF2 treated larvae showed a reduction which ranged from $74.3 \%$ to $99.5 \%$. From the aspect of residual effects on $\mathrm{L}_{3}, \mathrm{~L}_{4}$ developmental stages both formulations showed a residual effect throughout the experimental period. (Figure 5.)

Statistical analysis of the number of present $\mathrm{L}_{3}, \mathrm{~L}_{4}$ mosquito larvae compared to day zero in the control untreated water showed significantly lower values on days 21 $(\mathrm{p}<0.01), 35$ and $42(\mathrm{p}<0.05)$ after treatment.

Analysis of the statistical significance relative to day zero in waters treated with EF1 showed significantly higher values obtained on days 14 and $49(\mathrm{p}<0.05)$, and 21, 28, 35 and $42(\mathrm{p}<0.01)$.

Statistical analysis of the larvicidal effect of the formulation EF2 compared to day zero showed statistically significant effects on days $14,21,28,35$, and $42(\mathrm{p}<0.01)$.

Statistical analysis of the differences in larvae $\left(\mathrm{L}_{3}, \mathrm{~L}_{4}\right)$ number reduction between the two formulations confirmed that EF2 formulation compared to the control significantly reduced the number of larvae the first, $7^{\text {th }}, 14^{\text {th }}$ and $42^{\text {nd }}$ day $(p<0.05)$ and $21^{\text {st }}, 28^{\text {th }} 35^{\text {th }}$ and $49^{\text {th }}$ day $(\mathrm{p}<0.01)$. EF1 formulation significantly reduced the number of $\mathrm{L}_{3} \mathrm{~L}_{4}$ larvae the $2^{\text {nd }}$ and $3^{\text {rd }}$ day $(\mathrm{p}<0.05)$ and on the $14^{\text {th }}$, and $31^{\text {st }}(\mathrm{p}<0.01)$ compared to the control group. Only on the $3^{\text {rd }}$ day of the experiment a significant difference $(\mathrm{p}<0.05)$ between formulation EF1 and EF2 was recorded. Comparison of the reduction of the number of larvae $\left(\mathrm{L}_{3} \mathrm{~L}_{4}\right)$ showed no significant differences during the remaining time periods ( $\mathrm{p}>0.05)$. (Figure 6 ).

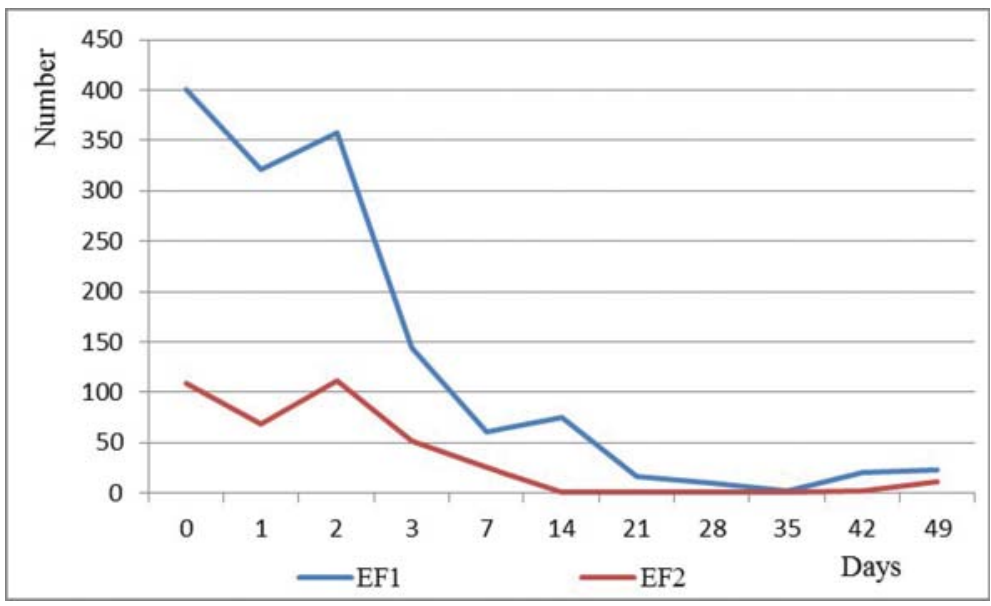

Figure 6. Comparative view of the effects of EF1 and EF2 formulations on the number of L3,L4 larvae 


\section{DISCUSSION}

The large number of aquatic habitats, as well as the fauna and flora-composition and environmental factors in the Belgrade area are optimal for the development of many different types of mosquito of the genera Culex, Anopheles, Aedes and Culliseta. Protection of people and animals during the season of high mosquito activity is impossible without the use of mosquito larvicides and adulticides.

Continuous application of synthetic insecticides to combat mosquito larvae (temefos, pirimiphos-methyl) without checking the status of resistance, as well as legislation that precludes their use were the basis for their replacement with alternative insecticides. In areas where these insecticides are used as alternatives, insect growth regulators are implemented with success. In our environment, insect growth regulators are not used for the control mosquito larvae.

The use of insect growth regulators is not recent [1,7]. The emergence of resistance in arthropods important to the health of humans and animals has accelerated the research of mechanisms of resistance to synthetic insecticides, as well as ways to avoid it by means of synthesis of new alternative substances [24-28]. Insect growth regulators in relation to synthetic insecticides, have lower toxicity to the environment and to non-target organisms [7,29].

Diflubenzuron is an insect growth regulator that inhibits the synthesis of chitin in mosquito larvae during molting by inhibiting chitin synthase enzymes, thus acting on the development of different biological stages. The larvae after ingestion of diflubenzuron can not complete the molting cycle which consequently leads to uncompleted biological development and death. The use of diflubenzuron for the suppression of mosquito larvae was recommended by the World Health Organization in 1982 [1].

Research of the product's different formulations, usually $25 \% \mathrm{WP}, 2 \%$ granules and tablets containing diflubenzuron was done before the WHO recommendations. Studies were done under laboratory and field conditions for different environments and with different types of mosquito larvae [29-31]. In these studies diflubenzuron has given good results for both initial and residual effects.

According to numerous studies WHO (1997) recommended the use of diflubenzuron in the form of $0.5 \%$ granules and $25 \%$ soluble powder at a dose of $25-100 \mathrm{~g} / \mathrm{ha}$ a.i., with toxic effects on mosquito larvae 1 to 4 weeks depending on water pollution [32]. The recommendation is for clean water $25-50 \mathrm{~g} / \mathrm{ha}$ a.i. and for polluted water 50 $100 \mathrm{~g} / \mathrm{ha}$. Numerous studies followed different habitats of the larvae of mosquitoes that preceded the WHO recommendations for the use of diflubenzuron at different concentrations and for different types of mosquito larvae. For drinking water, water canisters, and potable water wells, the recommended dose is $0.25 \mathrm{mg}$ diflubenzuron/ L [21]. 
The World Health Organization (2006) in two of its reports recommends the use of diflubenzuron in the first report at a dosage of $25-100 \mathrm{~g} /$ ha in the form of WP [7], and in the second report $2 \% \mathrm{G}$ (granules) in a dose of the active substance of 25-100 $\mathrm{g} / \mathrm{ha}$ resulting in a residual effect of a few weeks [22].

Taking into account the recommendations of the World Health Organization and the formulation of the conditions of their use, our research and the obtained results can be compared to the research conducted in similar environments as far as water quality is concerned [31,33]. There are no studies that relate to the type of carrier diflubenzuron as in our study of corncob and zeolite.

Mosquitoes are holometabolic insects. Their life cycle from the egg to the imago lasts depending on water temperature between 10 and 14 days. During the season $C x$. pipiens $L$ mosquitoes have more generations, the number depending on weather conditions. The number of larvae depends on the length of the life cycle and environmental conditions. The number of individual larval stages depends on the changes from one larval stage to the other, and later on, on the development of the imago from the pupa stage [8]. This might explain the rise and fall of the number of individuals in each developmental stage occurring in the water environment.

In this study which involved all larval stages the mortality of the larvae was low during the first days after treatment, but the percentage increased as time passed by. This means that both formulations have a poor initial effect, but a good residual effect which is in agreement with previous results published by a number of authors $[34,35]$.

In our study under field conditions the $1.0 \%$ diflubenzuron formulations displayed a good toxic effect on the larval stages of $C x$ pipiens $L$. during the 7 week trial. This coincides with the results obtained by a number of authors working in different geographical regions [36-38]. The effect of $2 \%$ diflubenzuron granules was determined in specific habitats [34]. Effects on the eradication of Cx. pipiens L and Ae. albopictus $S$. larvae which last for up to 6 weeks were obtained with the application of $2 \%$ diflubenzuron in granules and tablets in water pools $[39,40]$.

Studies on the effects of diflubenzuron in different aquatic environments have shown that diflubenzuron has a wide range of effects and its use is justified for water environments in which resistency is registered due to long term use of some larvicides.

The tested 1\% diflubenzuron formulations (EF1 and EF2) due to the results obtained on the reduction of $C x$. pipiens $L$ larvae in the initial and residual periods during the 7 weeks field trial period have shown that these formulations are a reliable mean of mosquito larvae control.

Statistical analysis has established a significant difference $(\mathrm{p}<0.05$ and $\mathrm{p}<0.01)$, when compared to the untreated control, in the reduction of present larvae, especially $\mathrm{L}_{3} \mathrm{~L}_{4}$, on the surfaces where the tested formulations EF1 and EF2 were applied. 


\section{REFERENCES}

1. World Health Organisation (WHO): Vector control in primary health care. The integration of vector control into primary health care. World Health Organization, Technical Report Series 755, Geneva, 1987, 6-15.

2. Pampiglione S, Canestri Trotii G, Rivasi F: Human dirofilariasis due to Dirofilaria (Nochtiella) repens: a review of world literature. Parassitol 1995, 37:149-93.

3. Hayes EB, Koman N, Nasci RS, Montgomery SP, O Leary DR, Campbell GL: Epidemiology and Transmission Dynamics of West Nile Virus Disese. Emerg Infect Dis 2005, 11:116773.

4. Dickinson K, Paskewitz S: Willingness to Pay for Mosquito Control: How important is West Nile Virus Risk Compared to the Nuisance of Mosquitoes? Vetor Borne Zoonotic Dis 2012, 10:886-92.

5. World Health Organisation (WHO): Lymphatic filariasis. Fact sheet No 102. [http://www. who.int/mediacentre/factsheets/fs102/en]

6. Chin J: Control of Communicable Diseases Manuel. 17 th Edition, Am Pub Health Assoc, Washington 2000, 624.

7. World Health Organisation (WHO): Report of the ninth WHOPES working group meeting. Chapter 2: Review of dimilin 2\% GR and 2\% DT. WHO/CDS/NTD/WHOPES/2006.2. Geneva, 2006, 4-36.

8. Becker N, Petrić D, Zgomba M, Boase C, Madon M, Dahl C, Kaiser, A: Mosquitoes and their control, Second Edition [ book review ]. J Eur Mosq Contol Assoc 2010, 28:246.

9. Centers for Disease Control (CDC): Larval Control and Other Vector Control Interventions. [http://www.cdc.gov/malaria/malaria_worldwide/reduction/vector_control.html]

10. Brown AW: Pest resistance to pesticides. In: White Stevens R, editor. Pesticides in the environment. New York Dekker 1971, 1 (part II) 457-552.

11. World Health Organization (WHO): Vector resistance to pesticides: Present status of pesticide resistance. Fifteenth report of the WHO Expert Committee on Vector Biology and Control. WHO Technical Report Series 818, Geneva ,1992, 2-17.

12. Whalon ME, Mota-Sanchez D, Hollingworth RM: Global Pesticide Resistance in Arthropods: Analysis of Global Pesticide Resistance in Arthropods. Cambridge, USA: CAB International; 2008, 5-32.

13. Borđoški M, Gligić A, Bošković R: Arbovirusne infekcije u SR Srbiji, Vojnosanit Pregl 1972, 29:173-5.

14. Stajković N. Vector Distribution and Control. Arch Toxicol Kinetic Xenob Metabol 1997, 5:63-9.

15. Dakić Z, Kulišić Z, Stajković N, Pelemiš M, Čobeljić M, Stanimirović Z: Ecology of Anopheles mosquitoes in Belgrade area, estimating vector potential for malaria retransmission. Acta Vet 2008, 58:603-15.

16. Kuljić-Kapulica N, Tasić D, Stajković N, Krstić M: Detection of antibodies to West Nile virus (WNV) in human sera. Med Riv 2009, 2:9-12.

17. Djordjević M, Stajković N, Pešić B: Detection of West Nile virus from mosquito Culexpipiens (fam:Culicidae) in Belgrade, Serbia 2012-2013 [abstract]. Book of Abstracts, International Meeting on Emerging Diseases and Surveillance, Vienna, Austria, 2014, 22:177.

18. Stajković N, Matić S, Antonović S: The Species of Anopheles and Their Sensitivity Insecticides. Pesticidi 1991, 6:97-104. 
19. Busvine JR: Insecticide-resistance in Culex pipiens fatigans. Bull Wld Org 1967, 37:287-92

20. Paul A, Harrington LC, Zhang L, Scott JG: Insecticide resistance in Culex pipiens from New York. J Am Mosq ConttolAssoc 2005, 21:305-9.

21. Marcombe S, Darriet F, Agnew P, Etienne M, Yp-Tcha MM, Yebakima A, Corbel V: Field efficacy of new larvicides products, for control of multi resistant Aedes aegypti populations in Martinique (French west Indies). Am J Trop Med Hyg 2011, 84:118-126.

22. World Health Organisation (WHO): Pesticides and Their Aplication. For the control of vectors and pests of public health importance. Chapter 3: Mosquitoes. Sixth edition. WHO/CDS/NTD/WHOPES/GCDPP/2006.1, Geneva, 2006, 22-37.

23. Utrio P: Identification key finnish mosquito larvae (Diptera, Culicidae). Ann Agric Fenn 1976, 15:128-36.

24. Wharton RH: Dieldrin resistance in Culex pipiens fatigans in Malaya. Bul Wld Hlth Org 1958, 18:657- 65 .

25. Hamdan H, Sofian-Azurin M, Nazni W, Lee HL: Insecticide resistance development in Culex quinquifasciatus (Say), Aedes aegypti (L.) and Aedes albopictus (Skuse) larvae against malathion, permethrin and temephos. Trop Biomed 2005, 22:45-52.

26. Cui F, Tan Y, Qiao CL: Filariasis vector in China: Insecticide resistance and population structure of mosquito Culex pipiens complex. Pest Manag Sci 2007, 63:453-8.

27. Martins AJ, Belinato TA, Lima JBP, Vale D: Chithin synthesis inhibitor effect on Aedes aegypti populations susceptible and resistance to organophosphate temephos. Pest Manag Sci 2008, 64: 676-80.

28. Suman SD, Parashar BD, Prakash S: Efficacy of various Insect Growth Regulators on Organophosphate Resistant Immatures of Culex quinquefasciatus (Diptera: Culicidae) from Different Geographical Areas of India. J Entomol 2010, 7:33-43.

29. Chamberlain WF: Insect growth regulating ageents for control of arthropods of medical and veterinary importance. J Med Entomol 1975, 12:395-400.

30. Mulla MS, Majori G, Darwazeh HA: Effects of the insect growth regulator Dimilin or TH 6040 on mosquitoes and some non-target organisms. Mosq News 1975, 35:211-6.

31. Axtell RC, Dukes JC, Edwards TD: Filed tests of diflubenzuron, methoprene, Flit mlo ${ }^{\circledR}$ and chloropiryfos for the control of Aedes taeniorbynchus larvae in Diked dredged spoil areas. Mosq News 1979, 39:520-6.

32. Rozendaal JA: Vector control. Methods for use by individuals and communities. Chapter 1: Mosquitos and other biting Diptera: Prevention of breeding. WHO, Geneva; 1997, 112 155.

33. Jahan N, RazaqJ, Jan A: Laboratory evaluation of Chitin Synthesis Inhibitors (Diflubenzuron and Buprofezin) Against Aedes aegypti Larvae from Lahore, Pakistan. Pakistan J Zool 2011, 43:1079-84.

34. Sadanandane C, Boopathi DOS PS, Jambulingam P: Efficacy of three formulations of diflubenzuron, an insect growth regulator, against Culex quinquefasciatus Say the vector of Bancroftian filariasis in India. Indian J Med Res 2012, 136:783-791.

35. Chen CD, Seleena B, Chiang YF, Lee HL: Field evalution of the bioefficacy of the diflubenzuron (Dimilin) against container-breeding Aedes sp. mosquitoes. Trop Biomed 2008, 25:80-86.

36. Cetin H, Yanikoglu A, Cilek JE: Efficacy of diflubenzuron, a chitin synthesis inhibitor, against Culex pipiens larvae in septic tank water. J Am Mosq Contol Assoc 2006, 22:343-5. 
37. Thavara U, Tawatsin A, Chansang C, Asavadachanukorn P, Zaim M, Mulla MS: Simulated field evalution of the efficacy of two formulations of diflubenzuron, a chitin synthesis inhibitor against larvae of Aedes aegypti (L.) (Diptera, Culicidae) in water-storage containers. Southeast. Asian J Trop Med Public Health 2007, 38:269-75.

38. Msangi S, Lyatuu E, Kweka EJ: Field and laboratory Evaluation of bioefficacy of an Insect Growth regulator (Dimilin) as a Larvicide against Mosquito and Housefly Larvae. J Trop Med 2011, 2011.

39. Romeo B, Alessandro A, Marco C, Roberta C, Luciano D, Maurizio M, Pilani R, Veronesi R, Chiot G, Lanza N: Efficacy and lasting activity of four IGRs formulations against mosquitoes in catch basins of northern Italy. Eur Mosq Bull 2009, 27:33-46.

40. Costa FM, Tadei WP: Laboratory toxicity evaluation of Diflubenzuron, a chitin-synthesis inhibitor, against Anopheles darlingi (Diptera, Culicidae). J Res Bilogy 2011, 6:444-50.

\title{
STATISTIČKA EVALUACIJA LARVICIDNOG EFEKTA DIFLUBENZURONA NA RAZLIČITE RAZVOJNE STADIJUME LARVI KOMARACA VRSTE CULEX PIPIENS
}

\author{
DJORDJEVIĆ Milutin, MIRILOVIĆ Milorad, STAJKOVIĆ Novica, JANKOVIĆ \\ Ljiljana, PEŠIĆ Branislav, BOKONJIĆ Dubravko, DJURIĆ Spomenka
}

U sredinama gde je kod larvi komaraca došlo do pojave rezistencije na insekticide, sve učestalije se koristi diflubenzuron. Za suzbijanje larvi komaraca u našoj sredini diflubenzuron nije korišćen. Ispitane su dve formulacije 1\% diflubenzurona (kočanka i zeolit) na komarcima vrste Culex pipiens L. (larve) na jednom kanalu u okolini Beograda. Efekat je praćen sedam nedelja posle primene formulacija. Formulacija EF1, ostvarila je redukciju larvi $\mathrm{L}_{1} \mathrm{~L}_{2}$ komaraca između 23,9 i 89,4\%, statistički značajno 21. i 28 dana $\mathrm{p}<0.001$, 35. i 42. dana $\mathrm{p}<0.01$ i 49. dana $\mathrm{p}<0.05$. Maksimalna redukcija larvi na formulaciji EF2 bila je 69,1\%, statistički značajno 28. dana i 42. dana $\mathrm{p}<0.001,35$. dana $\mathrm{p}<0.01$ i 21 . dana $\mathrm{p}<0.05$. Obe formulacije ostvarile su dobar rezidualni efekat na niže razvojne stadijume. Maksimalna redukcija larvi $\mathrm{L}_{3} \mathrm{~L}_{4}$ stadijuma na formulaciji EF1 iznosila je 97,4\%. Redukcija larvi bila je visoka između 7. dana i 42. dana (66,4$97 \%$ ), statistički značajne vrednosti su ostvarene u 21. dana, 28. dana i 35. dana, a kod formulacija EF2 maksimalna ostvarena redukcija brojnosti larvi je iznosila 99,5\%. Statistički značajne vrednosti redukcije brojnosti larvi komaraca dobijene su u 14 . dana, 21. dana, 28. dana, 35. dana i 42. dana. Između formulacija ne postoji značajna statistička razlika u vrednostima redukcije nižih stadijuma larvi, ali je kod viših EF1 bila efikasnija. 